\title{
Analisis Pengaruh Penerbitan Sukuk terhadap Abnormal Return Perusahaan di Indonesia
}

\author{
Riska Permatalia ${ }^{1)}$, Muhammad Istan ${ }^{2}$ \\ Magister Ekonomi Syariah UIN Sunan Kalijaga Yogyakarta \\ Institut Agama Islam Negeri Curup \\ permataliariska@gmail.com \\ Corresponding Author. Email: muhammadistan@iaincurup.ac.id
}

\begin{abstract}
Abstrak
Penelitian ini bertujuan untuk menganalisis pengaruh penerbitan sukuk terhadap abnormal return perusahaan di Indonesia. Perusahaan menerbitkan sukuk di pasar modal syariah sebagai alternatif tambahan dana untuk aktivitas perusahaan dan diharapkan dapat meningkatkan keuntungan dan harga saham, sehingga investor tertarik untuk melakukan investasi. Penelitian ini menggunakan metode deskriptif kuantitatif, data sekunder yang dari perusahaan yang listing di Bursa Efek Indonesia (BEI) tahun 2019 sebanyak 68 sampel. Pengujian model hipotesis menggunakan event study dengan uji statistik, uji asumsi klasik, dan regresi linier berganda dilakukan untuk menguji reaksi pasar atas peristiwa penerbitan sukuk pada variabel nilai penerbitan, waktu jatuh tempo, leverage perusahaan, total aset dan rating. Hasil penelitian yang mempengaruhi abnormal return adalah variabel jatuh tempo sukuk dan total aset pada $\alpha 5 \%$ dan $\alpha 10 \%$. Variabel nilai penerbitan sukuk, leverage perusahaan, dan rating berpengaruh tidak signifikan pada abnormal return. Hal ini menunjukkan bahwa informasi yang dibutuhkan investor untuk pilihan investasi belum terpenuhi.
\end{abstract}

Kata Kunci: Sukuk, abnormal return, event studi

\begin{abstract}
This study aimed to analyze the effect of sukuk issuance on abnormal returns of companies in Indonesia. The companies issued sukuk on the sharia's capital market as an alternative to additional funds for production and distribution. This was expected to increase profits and affect companies' stock price to drive investors. This study used descriptive quantitative method with data sourced from companies of 2019's Indonesia Stock Exchange (IDX) covering 68 samples. Analyses deployed statistical tests, classical assumption tests, and multiple linier regression to test market reactions to sukuk issuance on the issuance value, maturity date, company leverage, total assets, and rating. Results affecting abnormal returns were sukuk maturity date at $\alpha 5 \%$ and total assets at $\alpha 10 \%$. Concerning the value of sukuk issuance, company leverage, and rating, there were no significant effects on abnormal returns. This demonstrated that the information needed by investors had not been fulfilled.
\end{abstract}

Keywords: Sukuk, abnormal return, event study

\section{Pendahuluan}

Perekonomian Indonesia dengan bertumbuhnya pasar modal merupakan peran yang penting. Instrumen pasar modal seperti saham, obligasi, reksa dana ataupun derivatif keuangan lainnya baik secara konvensional maupun syariah terus mengalami peningkatan karenanya pasar modal merupakan sarana berinvestasi bagi pemilik modal dan sarana pendanaan bagi perusahaan juga pemerintah. Bagi perusahaan pasar modal menjadi sumber pembiayaan jangka panjang dalam mengembangkan usahanya, sebagai tempat penyebaran kepemilikan perusahaan kepada masyarakat, juga sebagai sikap keterbukaan dan profesionalisme perusahaan yang 
mendorong terciptanya iklim perusahaan yang sehat (Muklis, 2016).

Perusahaan akan memilih sumber dana eksternal baik saham maupun obligasi. Adanya variasi umum antara saham dan obligasi karena ketergantungannya pada nilai aset perusahaan yang sama (Cao et al., 2017). Sesuai dengan signalling theory perusahaan akan memberi sinyal pada investor bahwa perusahaannya lebih baik dari perusahaan lain (Spence, 1974) karena pendanaan mempunyai peran penting agar tujuan perusahaan dapat tercapai (Ida, 2010). Perusahaan dari negara berkembang telah secara signifikan meningkatkan obligasi, terutama setelah terjadinya krisis keuangan global. Secara internasional peningkatan tersebut seiring dengan meningkatnya pasokan modal oleh investor asing (Shi et al., 2020).

Penerbitan obligasi di Indonesia dibuktikan dengan total outstanding pada januari 2020 mencapai Rp 3,228.72 Triliun meningkat sebesar $14,17 \%$ dari januari 2019 yaitu Rp 2,828 Triliun. Dibalik peningkatan obligasi domestik karena adanya peningkatan pasokan dana investor domestik (Abraham et al., 2020). Obligasi merupakan surat utang jangka menengah maupun jangka panjang yang dapat diperjualbelikan dengan janji imbalan berupa bunga (kupon) periode tertentu dengan nilai nominal dan jangka waktu jatuh tempo asing ( Shi et al., 2020). Alternatif lain dari obligasi yang dinilai tidak sesuai dengan praktek ekonomi islam yang melarang penggunaan bunga pada instrumen tersebut. Hadirlah sukuk sebagai perkembangan dari industri keuangan syariah sesuai fatwa Dewan Syariah Nasional Nomor 32/DSN-MUI/IX/2002 tentang obligasi syariah.

Sukuk adalah sertifikat investasi yang dapat diterbitkan oleh negara atau perusahaan, persamaan dengan obligasi adalah memiliki tanggal jatuh tempo dan pemegang sukuk menerima aliran pendapatan reguler selama masa berlaku sertifikat dan pembayaran pada saat jatuh tempo (Godlewski et al., 2016). Perbedaaannya, obligasi tidak bergantung pada kelayakan penerbitnya, sedangkan sukuk dilihat perusahaan yang menghasilkan pendapatan dari aset yang mendasar harus sesuai dengan ketentuan syariah.
Harga sukuk dapat bervariasi sesuai dengan kelayakan kredit penerbitnya dengan nilai pasar dari aset. Kemudian nilai sertifikat yang dilunasi pada saat jatuh tempo harus mencerminkan harga pasar saat ini dari aset bukan dari jumlah asli yang diinvestasikan (Godlewski et al., 2016; Klein and Weill, 2016).

Indonesia merupakan negara dengan potensi pertumbuhan sukuk yang sangat tinggi, karena keunikan khusus yaitu populasi penduduk muslim terbanyak dunia sekitar $12,7 \%$ dari seluruh muslim di dunia (Qizam and Fong, 2019). Alasan lain mengapa perusahaan di negara berkembang seperti Indonesia dan Malaysia memilih menerbitkan sukuk karena adanya aimetri informasi serta preferensial pajak (Nagano, 2017). Perusahaan yang menerbitkan sukuk secara finansial lebih tidak stabil, dengan demikian mengekspos risiko kebangkrutan yang lebih tinggi dibandingkan menerbitkan obligasi ( $\mathrm{Ng}$ and Ariff, 2019). Dari segi investor, yang membuat sukuk lebih dipilih dari obligasi konvensional adalah pengembalian sukuk yang diharapkan dari aset utama melalui bagi hasil, sedangkan obligasi konvensional yang pengembaliannya berdasarkan pembayaran bunga (Razak et al., 2019).

Secara global perkembangan sukuk menurut IFDI, Indonesia menjadi Top Countries in Sukuk Outstanding 2018 menempati posisi ketiga dengan nilai sukuk outstanding US\$ 51 miliar. Sedangkan posisi pertama ditempati oleh Malaysia dengan nilai sukuk outstanding US\$ 219 miliar. Untuk nilai outstanding sukuk korporasi pada tahun 2018 meningkat $35,32 \%$ menjadi $\mathrm{Rp} 21,3$ triliun dibandingkan dengan periode sebelumnya. Jumlah sukuk outstanding sebanyak 99 seri, meningkat 25,32\% dibandingkan jumlah seri sukuk tahun lalu.

Secara nasional berdasarkan Laporan Keuangan Syariah Indonesia tahun 2019 sukuk korporasi di Indonesia menunjukkan peningkatan yang signifikan dalam lima tahun terakhir, terbukti dengan 143 jumlah sukuk dengan nilai 29,83 triliun rupiah. Sukuk korporasi outstanding pada tahun 2019 mengalami peningkatan sebesar 44,44\% dibandingkan tahun 2018 yang menyumbang sebesar 6,53\% market share nilai efek Indonesia. Meski demikian sukuk 
negara masih mendominasi dengan nilai 740,62 triliun rupiah dengan jumlah 67 sukuk yang menyumbang market share nilai efek Indonesia sebesar 18,45\%.

Perusahaan yang telah go public akan terus mengembangkan sumber dana eksternal baik sukuk ataupun saham. Penelitian ini berfokus pada perusahaan yang menerbitkan sukuk apakah akan menyebabkan terjadinya abnormal return? Berdasarkan signally teory investor akan memberikan tanggapan atas penerbitan sukuk yang dikeluarkan oleh perusahaan (Kang et al., 1995; Ashhari et al., 2009; Mujahid, 2010; Kim dan Abdullah, 2012; Pratama, 2013; Sari, 2014; Savitri, 2015; Ainurrochma dan Priyadi, 2016; Hardianti dan Widarjono, 2017; Iskandar dan Ridwan, 2019; Syarifudin et al., 2019) .

Gairah investasi di pasar modal baik konvensional maupun syariah oleh investor menjadi suatu pertanda berkembangnya industri di negara tersebut (Abraham et al., 2020). Keputusan untuk investasi dari investor akan diuji dalam penelitian ini yang menghubungkan penerbitan sukuk dengan saham. Mujahid (2010), Pratama (2013), dan Savitri (2015) menghasilkan penelitian bahwa penerbitan obligasi syariah tidak berpengaruh pada reaksi pasar modal syariah yaitu return saham. Berbeda dengan hasil Iskandar dan Ridwan (2019) dan Syarifudin et al. (2019) penerbitan sukuk atas variabel nilai dan rating penerbitan sukuk berpengaruh positif terhadap reaksi pasar modal syariah yang menggunakan abnormal return.

Savitri (2015) berpendapat bahwa penerbitan sukuk melalui variabel nilai dan rating penerbitan bisa saja akan berdampak pada saham perusahaan seiring berubahnya waktu dan masa. Seperti halnya Iskandar dan Ridwan (2019) dan Syarifudin et al. (2019) yang menemukan hasil penelitian sesuai dengan pendapat Savitri (2015). Karena alasan inilah peneliti tertarik untuk meneliti dan mengembangkan kembali hasil penelitian-penelitian terdahulu (Iskandar and Ridwan, 2019; Savitri, 2015; Syarifudin et al., 2019) dengan judul analisis penerbitan sukuk terhadap abnormal return perusahaan Indonesia dengan rumusan masalah bagaimana pengaruh penerbitan sukuk terhadap abnormal return perusahan di Indonesia. Berdasarkan hal tersebut penelitian ini bertujuan untuk menganalisis pengaruh penerbitan sukuk terhadap abnormal return perusahaan di Indonesia. Adapun kontribusi dari penelitian ini bagi pengguna informasi portofolio pasar modal syariah, pembuat kebijakan serta civitas akademik untuk memperdalam literasi dalam menentukan investasi apa yang sebaiknya dilakukan pada keadaan tertentu dari informasi yang didapatkan oleh investor.

Agaknya terdapat perbedaan hasil dari penerbitan obligasi maupun sukuk pada return saham perusahaan di Indonesia maupun di negara lain. Hal ini dikarenakan informasi yang dihasilkan setelah penerbitan obligasi atau sukuk bisa menjadi positif atau negatif tergantung seberapa efisien pasar di suatu negara. Penerbitan obligasi atas respon investor saham sebagai good news atau berita baik dan dibuktikan dengan return saham yang positif (Kang et al., 1995; Kim dan Abdullah, 2012). Artinya semakin baik berita yang direspon investor maka semakin tinggi return saham yang diperoleh perusahaan. Hal ini menandakan pasar yang efisien. Pada negara Malaysia adanya pengaruh positif atas penerbitan sukuk terhadap return saham (Ashhari et al., 2009).

Pada negara Korea penelitian yang dilakukan (Kim and Han, 2019) pada tahun 2000 hingga 2015 efek pengumuman penerbitan obligasi konversi memiliki pengaruh yang positif secara signifikan terhadap pengembalian abnormal kumulatif pada kisaran waktu pengumuman tersebut. Perusahaan akan meningkatkan pengeluaran belanja modal mereka setelah menawakan obligasi sehingga pasar bereaksi positif karena tingginya ekspektasi investasi efek dari informasi asimetris. Sedangkan di Indonesia Mujahid (2010), Pratama (2013), dan Savitri (2015) menghasilkan penelitian bahwa penerbitan obligasi syariah tidak berpengaruh pada reaksi pasar modal syariah yaitu return saham.

Berbeda dengan hasil Iskandar dan Ridwan (2019) dan Syarifudin et al. (2019) penerbitan sukuk atas variabel nilai dan rating penerbitan sukuk berpengaruh positif terhadap reaksi pasar modal syariah yang menggunakan abnormal return. Penelitian Sari (2014) yang menggunakan dua 
pengujian pertama, uji paired sample test menghasilkan bahwa tidak ada perbedaan signifikan return saham (abnornmal return) sebelum dan sesudah pengumuman penerbitan obligasi syariah (sukuk). Kedua, uji one sample t-test menghasilkan bahwa tidak terdapat efek dari peristiwa pengumuman penerbitan sukuk ijarah terhadap return saham pada hari sekitar peristiwa penerbitan sukuk ijarah.

Variabel pengembangan lainya dari penelitian Ainurrochma dan Priyadi (2016) menunjukkan bahwa rating penerbitan sukuk berpengaruh terhadap reaksi pasar (return saham) sedangkan nilai penerbitan dan Debt to Equity Ratio (DER) tidak berpengaruh terhadap reaksi pasar (return saham). Pasar saham tidak terlalu responsif baik pada penerbitan sukuk maupun obligasi, hal ini ditunjukkan pada penelitian Hardianti dan Widarjono (2017) bahwa hanya nilai jatuh tempo sukuk dan obligasi saja yang signifikan terhadap return saham, sedangkan nilai penerbitan, total hutang perusahaan, dan besarnya aset perusahaan tidak signifikan berpengaruh pada return saham. Hal ini mengindikasikan bahwa informasi atas penerbitan sukuk yang didapatkan investor tidak bermakna.

Savitri (2015) berpendapat bahwa penerbitan sukuk melalui variabel nilai dan rating penerbitan bisa saja akan berdampak saham perusahaan dalam beberapa waktu kedepan. Seperti halnya Iskandar dan Ridwan (2019) dan Syarifudin et al. (2019) yang menemukan hasil penelitian sesuai dengan pendapat Savitri (2015). Karena alasan inilah peneliti tertarik untuk meneliti dan mengembangkan kembali hasil penelitian-penelitian terdahulu.

Uraian literatur yang telah dipaparkan, peneliti bermaksud mengembangkan kembali penelitian dari (Hardianti and Widarjono, 2017) dan melengkapi atas hasil penelitian-penelitian terdahulu (Kang et al., 1995; Ashhari et al., 2009; Mujahid, 2010; Kim dan Abdullah, 2012; Pratama, 2013; Sari, 2014; Savitri, 2015; Ainurrochma dan Priyadi, 2016; Hardianti dan Widarjono, 2017; Iskandar dan Ridwan, 2019; Syarifudin et al., 2019) terkait dengan penerbitan sukuk terhadap reaksi pasar modal yang menggunakan abnormal return. Perbedaannya terletak pada variabel independen yang diteliti yaitu diukur dari penerbitan sukuk berdasarkan nilai penerbitan, jatuh tempo, dan rating perusahan di Indonesia, juga dari segi kemampuaan perusahaannya diukur dengan total hutang dan aset perusahaan. Alasan Variabel independen ini dipilih karena berdasarkan hasil literatur terdahulu, yaitu memiliki perbedaan hasil penelitian.

\section{Kajian Teoritik}

\section{Asymmetric Information}

Adanya informasi yang berlainan yang diperoleh antara pihak investor dan agen perusahaan dalam kegiatan ekonomi (OJK, 2016). Asymmetric information atau informasi asimetri dibagi menjadi dua bentuk, pertama hidden knowledge menggambarkan situasi di mana satu pihak memiliki informasi lebih lanjut dari pihak lain pada tipe dari barang atau kontrak variabel yang diperdagangkan. Kedua, hidden action di mana salah satu pihak dapat mempengaruhi dengan tindakan dari tipe barang atau kontrak variabel yang diperdagangkan tetapi tindakan ini tidak dapat diamati oleh pihak lain. Pada penelitian ini teori asymmetric information atau informasi asimetri digunakan ditandai dengan kesesuaian atau tidaknya informasi penerbitan sukuk pada perusahaan di Indonesia yang dimiliki investor atas reaksi pasar modal.

\section{Signalling Theory}

Teori ini dikemukan oleh Akerlof (1970) dan Arrow (1972) serta pengembangan yang dilakukan oleh Spence (1974) yang menyatakan bahwa pemberian sinyal dengan biaya tertentu yang sulit ditirukan jika biayanya sangat tinggi kepada pasar modal untuk mengatakan bahwa perusahaan dirinya lebih baik dari perusahaan lainnya. Penelitian Alam et al., (2013) menemukan bahwa pengumuman sukuk memberikan sinyal negatif pada pasar saham, karena investor berasumsi perusahaan tidak cukup kuat lebih memilih menerbitkan sukuk untuk berbagi risiko kerugian dalam kasus terburuk.

Hubungan teori sinyal pada penelitian ini bahwa adanya perubahan harga saham dari reaksi pasar atas penerbitan obligasi yang memiliki informasi bermakna dan berarti bagi investor dan juga pasar. Karena teori ini berasumsi jika perusahaan 
menerbitkan obligasi ketika manajemen menilai harga saham dinilai lebih rendah oleh pasar (undervalued) dan di anggap sebagai sinyal positif. Sebaliknya, penerbitan saham ketika manajemen menilai harga saham lebih tinggi oleh pasar (overvalued) dan di anggap sebagai sinyal negatif (Rachman and Ervina, 2017). Sederhananya, sinyal positif maka investor tertarik untuk berinvestasi. Namun, jika sinyal negatif maka investor akan beralih pada investasi lainnya tentu yang lebih menguntungkan (Shi et al., 2020).

\section{Sukuk}

Sukuk terdiri dari kelas instrumen keuangan syariah tertentu yang dapat diterbitkan oleh entitas perusahaan dan negara. Sukuk memiliki kesamaan dengan obligasi, memiliki nilai nominal, tanggal jatuh tempo, tingkat margin dan memberikan aliran arus kas secara teratur kepada investor termasuk modal pengembalian dana di akhir periode (Godlewski et al., 2016; Klein and Weill, 2016). Sukuk adalah pembiayaan atau pinjaman terstruktur dari pemegang sukuk kepada penerbit (Razak et al., 2019). Sukuk didefinisikan sebagai sertifikat yang dapat diperdagangkan kepemilikan yang memberikan hak aliran pendapatan dari investasi suatu proyek. Perbedaan dengan obligasi dari segi struktur, keuangan Islam mengharuskan setiap transaksi komersial berdasarkan aset rill (Klein and Weill, 2016), adanya Special Purpose Vehicle (SPV) yaitu badan hukum yang didirikan khusus untuk penerbitan sukuk. Tugasnya melakukan pensekuritian aset, mengikuti kontrak tertentu antara penjual sukuk kepeda investor, penentuan keuntungan, penebusan sukuk. SPV sangat berkontribusi sebagai penjamin pelaksanaan sukuk sesuai aturan yang telah ada (Shanmugam dan Zahari, 2009).

Sukuk dapat berbentuk cost-plus penjualan (murabahah), kontrak pembayaran di muka (salam), kontrak usaha (istisna') atau sewa (ijarah). Hal ini sesuai fatwa Dewan Syariah Nasional Nomor 32/DSN-MUI/IX/2002 tentang obligasi syariah. Hubungan penerbitan sukuk pada penelitian ini dengan saham adanya asumsi informasi strategis yaitu sumber dana dan penggunaan aset yang memiliki biaya tetap oleh perusahaan untuk meningkatkan keuntungan potensial bagi investor atau pemegang saham dan biasanya di sebut dengan leverage perusahaan (Sartono, 2008).

\section{Abnormal Return Saham}

Return dapat dihitung antara selisih harga sekarang relatif terhadap harga sebelumnya. Return adalah hasil kebijakan investasi perusahaan yaitu keuntungan yang diperoleh perusahaan (Sari, 2014). Sedangkan abnormal return adalah perbedaan nilai return (Hardianti and Widarjono, 2017). Perbedaan ini adalah kelebihan dari return normal yang merupakan expected return atau imbal hasil yang diharapkan dan belum terjadi terhadap abnormal return yang merupakan kelebihan dari return sebenarnya yang telah terjadi. Hubungan abnormal return digunakan pada penelitian ini adalah jika terjadi abnormal return positif maka informasi penerbitan obligasi yang dimiliki bermakna bagi investor dan berpengaruh terhadap harga saham, seperti halnya penelitian Iskandar dan Ridwan (2019) dan Syarifudin et al. (2019). Begitupun sebaliknya, tergantung dari hasil abnormal return positif atau negatif.

\section{Materials and Methods}

Penelitian ini menggunakan metode kuantitatif deskriptif dengan alat statistik, pengujian hipotesis menggunakan event study atau studi peristiwa untuk menguji reaksi pasar atas peristiwa penerbitan sukuk pada variabel nilai penerbitan, waktu jatuh tempo, leverage perusahaan, total aset dan rating.

Penelitian ini menggunakan data sekunder yang bersumber dari perusahaan yang tercatat di Bursa Efek Indonesia (BEI) data statistik tahun 2019. Sampel penelitian ini menggunakan teknik purposive sampling yang harus memenuhi kriteria: 1)perusahaan yang dipilih harus sudah go public di mana perusahaan mempunyai kewajiban tanggung jawab atas kinerja perusahaan dengan membagikan laporan keuangannya. 2) perusahaan penerbit sukuk yang terdaftar pada BEI. Hasilnya terdapat 7 perusahaan dengan 68 sukuk yang diterbitkan dari tahun 2014-2019. 
Penelitian ini menggunakan analisis data regresi linier berganda dengan persamaan :

$$
Y=\beta_{0}+\beta_{1} X_{1}+\beta_{2} X_{2}+\beta_{3} X_{3}+\beta_{4} X_{4}+\beta_{5} X_{5}+\varepsilon_{i}
$$

Dimana :

$\mathrm{Y}=$ Abnormal return

$\beta=$ Koefisien

$\mathrm{X}_{1} \quad=$ Nilai penerbitan obligasi

$\mathrm{X}_{2} \quad$ = Waktu jatuh tempo obligasi

$\mathrm{X}_{3}=$ Leverage perusahaan

$\mathrm{X}_{4}=$ Total aset perusahaan

$\mathrm{X}_{5} \quad$ = Rating penerbitan obligasi

\section{Definisi Operasional Variabel Variabel Dependen}

Abnormal return digunakan untuk mengukur kinerja harga saham ketika perusahaan menerbitkan sukuk. hal ini sebagai cerminan dari reaksi investor atas pengumuman penerbitan sukuk tersebut (Alam et al., 2013). Untuk mengukur abnormal return dengan cara menghitung return terlebih dahulu.

$R_{i t}=\frac{P_{i t}-P_{i t-1}}{P_{i t-1}}$

Dimana :

$R_{i t}=$ Return sesungguhnya

$P_{i t}=$ Harga sekarang waktu ke-t

$P_{i t-1}=$ Harga sebelum waktu ke-t

Penelitian ini menggunakan market adjusted model untuk menghitung tingkat return ekspektasi saham perusahaan yang menduga bahwa return indeks pasar pada waktu berjalan untuk mengestimasi return sukuk.

$R_{m t}=\frac{I H S G_{t}-I H S G_{t-1}}{I H S G_{t-1}}$

Dimana :

$R_{m t} \quad=$ return indeks pasar saham

$I H S G_{t} \quad=$ Indeks harga saham gabungan tahun

ke-t

IHSG $_{t-1}=$ IHSG tahun sebelum waktu ke-t

Dimana :

$$
E\left(R_{j t}\right)=R_{f t}+\beta\left(R_{\text {m } t}-R_{f t}\right)
$$

$\mathrm{E}\left(\mathrm{R}_{\mathrm{jt}}\right)$ : Return ekspektasi

$\mathrm{R}_{\mathrm{ft}}$ : Nilai suku bunga
$\mathrm{R}_{\text {mot }}:$ Return indeks pasar saham

$$
A R_{\text {jt }}=R_{\text {jt }}-E\left(R_{\text {jt }}\right)
$$

Dimana :

$\mathrm{AR}_{\mathrm{jt}} \quad$ : Abnormal return

$\mathrm{R}_{\mathrm{jt}} \quad$ : return saham 1 pada periode $\mathrm{t}$

$\mathrm{E}\left(\mathrm{R}_{\mathrm{jt}}\right)$ : Return ekspektasi saham 1 pada periode $\mathrm{t}$

\section{Variabel Independen}

Penelitian ini menggunakan variabel independen penerbitan sukuk diukur dari pertama, nilai nominal penerbitan sukuk dengan total ekuitas perusahaan. Jenis dan jumlah sukuk yang diterbitkan perusahaan bervariasi (Syarifudin et al., 2019) tergantung dari kebutuhan dan tujuan perusahaan (Ida, 2010). Semakin besar nilai yang diterbitkan maka semakin besar risiko gagal bayar, maka nilai nominal penerbitan sukuk berpengaruh negatif terhadap abnormal return.

Variabel kedua, waktu jatuh tempo sukuk. Jika waktu jatuh tempo semakin panjang, maka investor akan memperoleh nilai kupon yang tinggi (Hardianti and Widarjono, 2017). Namun, risiko dari suatu peristiwa akan semakin tinggi yang berkemungkinan kinerja keuangan perusahaan bisa menurun, maka jatuh tempo berpengaruh negatif terhadap imbal hasil.

Variabel ketiga, total hutang perusahaan yang diukur dengan rasio leverage jumlah hutang terhadap modal perusahaan yang merupakan kewajiban jangka panjang perusahaan yang semakin besar seiring dengan besarnya hutang perusahaan untuk membiayai modal usahanya. Jika terlalu besar maka akan menurunkan kinerja keuangan perusahaan (Ainurrochma dan Priyadi, 2016). Maka total hutang berpengaruh negatif terhadap abnormal return.

Variabel keempat, total aset perusahaan. Bersumber dari laporan keuangan yang diterbitkan perusahaan. Semakin besar aset perusahaan mengindikasikan semakin besar return yang diharapkan (Hardianti and Widarjono, 2017), maka total aset berpengaruh positif terhadap abnormal return.

Variabel kelima, rating penerbit sukuk, yang dikonversikan dalam bentuk interval bersumber dari PT Pemeringkat Efek Indonesia (PEFINDO). Investor akan memilih perusahaan dengan rating yang tinggi 
untuk menghidari risiko dan mendapatkan return tinggi pula (Ainurrochma dan Priyadi, 2016). Maka, rating penerbit sukuk berpengaruh positif terhadap abnormal return.

\section{Hasil dan Pembahasan}

Penelitian ini menggunakan uji asumsi klasik yang terdiri dari uji multikolineritas, uji autokorelasi, uji heteroskedastisitas, dan uji normalitas. Sebelumnya untuk mengetahui nilai rata-rata, nilai tertinggi, nilai terendah dan standar deviasi setiap data dari variabel seperti tabel 1 sebagai berikut:

TABEL 1

STATISTIK DESKRIPTIF

\begin{tabular}{|c|c|c|c|c|c|}
\hline & SER & JT & DER & SIZE & RATING \\
\hline Mean & 0.011860 & 5.158421 & 2.862317 & 7.061742 & 17.97059 \\
\hline Maximum & 0.059524 & 10.02740 & 5.740000 & 16.56804 & 19.00000 \\
\hline Minimum & 0.000261 & 1.019178 & 0.910000 & 2.529822 & 12.00000 \\
\hline Std. Dev. & 0.011574 & 2.634168 & 1.227525 & 2.850667 & 2.278849 \\
\hline $\begin{array}{c}\text { Observatio } \\
\text { ns }\end{array}$ & 68 & 68 & 68 & 68 & 68 \\
\hline
\end{tabular}

Tabel 1 menjelaskan hasil statistik deskriptif bahwa nilai penerbitan sukuk (SER) dari perusahaan tertinggi sebesar 0.059524 dengan nilai terendah sebesar 0.000261 dari total ekuitas perusahaan. Untuk variabel jatuh tempo (JT) dengan nilai tertinggi sebesar 10.02740 dan nilai terendah sebesar 1.019178 . Variabel rasio leverage perusahaan (DER) memiliki nilai tertinggi sebesar 5.740000 dan nilai terendah sebesar 0.910000. Variabel total aset perusahaan (SIZE) memiliki nilai tertinggi sebesar 16.56804 dan nilai terendah sebesar 2.529822. Variabel Rating memiliki nilai tertinggi sebesar 19.00000 dan nilai terendah sebesar 12.00000 .

TABEL 2

HASIL ORDINARY LEAST SQUARES

\begin{tabular}{|c|c|c|c|c|}
\hline \multicolumn{5}{|c|}{$\begin{array}{c}\text { Dependent Variable: ABR } \\
\text { Method: Least Squares } \\
\text { Sample: } 168 \text { Included observations: } 68\end{array}$} \\
\hline Variable & Coefficient & Std. Error & t-Statistic & Prob. \\
\hline
\end{tabular}

\begin{tabular}{cccrr} 
C & 0.0125 & 0.056671 & 0.2222 & 0.8249 \\
SER & 0.1041 & 0.536871 & 0.1940 & 0.8467 \\
JT & -0.0041 & 0.002106 & -1.9897 & 0.0510 \\
DER & -0.0022 & 0.006463 & -0.3425 & 0.7331 \\
SIZE & -0.0043 & 0.002404 & -1.7888 & 0.0785 \\
Rating & 0.0022 & 0.003521 & 0.6455 & 0.5210 \\
\hline \hline & & & \\
R-squared & 0.1371 & Mean dependent var & -0.0036 \\
$\begin{array}{c}\text { Adjusted } \\
\text { R-squared } \\
\text { S.E. of } \\
\text { regression }\end{array}$ & 0.06761 & S.D. dependent var & 0.0424 \\
Sum squared & 0.0409 & Akaike info criterion & -3.4681 \\
resid & 0.1040 & Schwarz criterion & -3.2722 \\
Log likelihood & 123.91 & Hannan-Quinn criter. & -3.3905 \\
$\begin{array}{c}\text { F-statistic } \\
\text { Prob(F-statistic) }\end{array}$ & 1.9717 & Durbin-Watson stat & 0.8852 \\
\hline & 0.0953 & &
\end{tabular}

Persamaan regresi :

$\mathrm{ABR}=$

$0.0125923489337+0.104197017348 *$ SER-0.

$00419106868472 * J T-0.00221418403471 * \mathrm{D}$

ER-0.00429958241336*SIZE +

$0.00227314733198 *$ RATING

Tabel 2 menunjukkan hasil regresi linier berganda atau uji ordinary least squares untuk melihat sejauhmana variabel independen yaitu nilai penerbitan sukuk (SER), jatuh tempo (JT), leverage perusahaan (DER), total aset perusahaan (SIZE), dan rating penerbitan sukuk (RATING) mempengaruhi variabel dependen yaitu abnormal return perusahaan yang menerbitkan sukuk di Indonesia. Tahapan-tahapan yang harus di uji pada model penelitian ini yaitu uji uji multikolineritas, uji autokorelasi, uji heteroskedastisitas, dan uji normalitas berikut ini.

\section{Uji Multikolineritas}

Tujuan dari pengujian multikolineritas untuk mengetahui apakah model regresi pada penelitian ini ada kolerasi yang tinggi antar variabel independen. Jika ditemukan kolerasi yang tinggi pada variabel independen maka model tersebut memiliki gejala multikolineritas. Model penelitian ini menunjukkan tidak ada gejala multikolineritas, artinya antara variabel independen tidak terjadi korelasi. Variance Inflation Factors (VIF) harus < 10 dan hasil uji pada tabel 3 nilai VIF dari setiap variabel independen $<10$. 
TABEL 3

UJI MULTIKOLINERITAS

VARIANCE INFLATION FACTORS

SAMPLE: 168

INCLUDED OBSERVATIONS: 68

\begin{tabular}{ccc}
\hline \hline Variable & VIF & Keterangan \\
& & \\
\hline \hline SER & 1.541517 & Tidak ada multikolinieritas \\
\hline JT & 1.229066 & Tidak ada multikolinieritas \\
\hline DER & 2.513094 & Tidak ada multikolinieritas \\
\hline SIZE & 1.874463 & Tidak ada multikolinieritas \\
\hline RATING & 2.570958 & Tidak ada multikolinieritas \\
\hline \hline
\end{tabular}

\section{Uji Autokorelasi}

Uji Breusch-Godfrey Serial Correlation LM digunakan untuk menguji ada atau tidak adanya korelasi serial dalam model regresi diantara variabel-variabel yang diamati. Jika nilai prob. Chi square < 0,05 maka terjadi gejala autokorelasi sedangkan jika >0,05 maka tidak terjadi gejala autokorelasi. Hasilnya prob chi square sebesar 0,1591 > 0,05 maka dapat disimpulkan bahwa tidak terjadi gejala autokorelasi pada model penelitian.

\section{Uji Heteroskedastisitas}

Adanya ketidaksamaan varian dari residual untuk semua pengamatan pada model regresi disebut heteroskedastisitas. Dalam model regresi prasyarat yang harus terpenuhi adalah tidak adanya gejala heteroskedastisitas dengan mengetahui jika nilai prob chi square < 0,05 maka terjadi gejala heteroskedastisitas sedangkan jika nilai prob chi square > 0.05 maka tidak terjadi gejala heteroskedastisitas pada model penelitian. Hasil uji dengan metode white menunjukkan prob chi square sebesar $0.9599>0,05$ maka dapat disimpulkan tidak terjadi gejala heteroskedastisitas dalam model penelitian ini.

\section{Uji Normalitas}

Pendekatan analisis mengunakan grafik normal probability plot dengan nilai residual terdistribusi secara normal apabila garis (titik-titik) yang menggambarkan data sesungguhnya akan mengikuti atau merapat ke garis diagonalnya. Nilai probabilitas Jarque Berra sebesar 0,513395 > 0,05, artinya residual data penelitian terdistribusi secara normal.

Setelah melakukan uji asumsi klasik, selanjutnya deskriptif analisis dari tabel 2 nilai $\mathrm{R}^{2}$ sebesar 0.137193 artinya menunjukkan bahwa variasi antara variabel dependen bisa dijelaskan oleh variabel independen sebesar $13,7 \%$ dan $86,3 \%$ dijelaskan oleh variabel lainnya. Hasil pada tabel 2 uji hipotesis dengan menggunakan uji t menunjukkan pengaruh dari setiap variabel independen yaitu nilai penerbitan sukuk, jatuh tempo, leverage perusahaan, total aset, dan rating terhadap variabel dependen yaitu abnormal return. Variabel independen yang berpengaruh secara parsial adalah variabel jatuh tempo pada $\alpha 5 \%$ semakin panjang jangka waktu, maka semakin tinggi nilai kupon yang diperoleh investor sukuk. Variabel total aset pada $\alpha 10 \%$ terhadap variabel abnormal return. Semakin besar aset perusahaan maka semakin besar return yang didapatkan.

Secara simultan variabel independen nilai penerbitan sukuk, jatuh tempo, leverage perusahaan, total aset, dan rating tidak berpengaruh signifikan pada $\alpha 5 \%$ terhadap abnormal return. Namun berpengaruh signifikan pada $\alpha 10 \%$. Temuan analisis penerbitan sukuk terhadap abnormal return di perusahaan Indonesia mengindikasi terkait informasi yang dibutuhkan oleh investor sebelum memilih untuk melakukan investasi belum terpenuhi. Hubungan penerbitan sukuk pada penelitian ini dengan saham adanya asumsi informasi strategis yaitu sumber dana dan penggunaan aset yang memiliki biaya tetap oleh perusahaan untuk meningkatkan keuntungan potensial bagi investor atau pemegang saham dan biasanya di sebut dengan leverage perusahaan (Sartono, 2008).

Berbanding terbalik dengan hasil penelitian Savitri (2015) berpendapat bahwa penerbitan sukuk melalui variabel nilai dan rating penerbitan bisa saja akan berdampak pada saham perusahaan dalam beberapa waktu kedepan. Seperti halnya Iskandar dan Ridwan (2019) dan Syarifudin et al. (2019) yang menemukan hasil penelitian sesuai dengan pendapat 
Savitri (2015) namun tidak sejalan hasilnya pada penelitian ini. Perusahaan akan mendapatkan tambahan dana dengan menerbitkan sukuk yang akan meningkatkan produksi dan distribusi searah dengan meningkatnya jumlah permintaan, maka keuntungan yang diperoleh pun meningkat sehingga investor tertarik untuk berinvestasi pada perusahaan.

\section{Kesimpulan}

Analisis penerbitan sukuk dengan variabel nilai penerbitan, jatuh tempo, leverage perusahaan, total aset dan rating terhadap abnormal return perusahaan Indonesia yang go public dan tercatat di BEI dengan menggunakan regresi linier berganda dan uji asumsi klasik. Hasil dari penelitian ini yang mempengaruhi abnormal return adalah variabel jatuh tempo sukuk pada $\alpha 5 \%$ dan variabel total aset pada $\alpha$ $10 \%$. Untuk variabel nilai penerbitan sukuk, leverage perusahaan, dan rating berpengaruh tidak signifikan pada abnormal return. Hal ini menunjukkan bahwa informasi yang dibutuhkan oleh investor untuk memilih melakukan investasi belum terpenuhi.

\section{Saran}

Penelitian ini memberikan kontribusi bagi para investor untuk melihat kinerja perusahaan dan karateristik sukuk yang diterbitkan oleh perusahaan dan bagi perusahaan penerbit sukuk agar bisa melihat peluang pada kondosi ekonomi di Indonesia sehingga bisa mendapatkan sumber dana sebagai tambahan untuk produksi dan distribusi. Bagi peneliti selanjutnya bisa membandingkan dengan obligasi atau sukuk secara global.

\section{Daftar Pustaka}

A. Abraham, F., Cortina, J.J., Schmukler, S.L., 2020. The Rise of Domestic Capital Markets for Corporate Financing: Lessons from East Asia. J. Bank. Finance 105987.

B. Ainurrochma, E., Priyadi, M.P., 2016. Pengaruh Nilai dan Rating Penerbitan Sukuk serta DER Perusahaan terhadap Reaksi Pasar. J. Ilmu Dan Ris. Akunt. 6(12).

C. Akerlof, G., 1970. The Market for "Lemons":
Qualitative Uncertainty and the Market Mechanism. Q. J. Econ. 84(3), 488-500.

D. Alam, N., Hassan, M.K., Haque, M.A., 2013. Are Islamic bonds different from conventional bonds? International evidence from capital market tests. Borsa Istanb. Rev. 13, 22-29.

E. Arrow, J.., 1972. Some Models of Racial Discrimination in the Labor Market. AH Pascal Ed.

F. Ashhari, Z.., Chun, L.., Nassir, 2009. Conventional Vs Islamic Bond Announcements: The Effects on Shareholders Wealth. Int. J. Bussiness Manag. 4, 105-111.

G. Cao, N., Galvani, V., Gubellini, S., 2017. Firm-specific stock and bond predictability: New evidence from Canada. Int. Rev. Econ. Finance 51, 174-192.

H. Godlewski, C.J., Turk-Ariss, R., Weill, L., 2016. Do the type of sukuk and choice of shari'a scholar matter? J. Econ. Behav. Organ. 132, 63-76.

I. Hardianti, N.I., Widarjono, A., 2017. Dampak Penerbitan Sukuk dan Obligasi Konvensional terhadap Return Saham Perusahaan di Indonesia. J. Ekon. Keuang. Islam 3(1), 43-51.

J. Ida, 2010. Pemilihan Sumber Pendanaan Perusahaan Berdasarkan Hipotesis Pecking Order J. Akunt. 2.

K. Iskandar, M., Ridwan, 2019. Pengaruh Penerbitan Sukuk terhadap Reaksi Pasar (Survey terhadap Perusahaan-Perusahaan yang Menerbitkan Obligasi Syariah yang Terdaftar di Bursa Efek Indonesia Selama Tahun 2015). J. Ilm. Mhs. Ekon. Akunt. JIMEKA 4(3), 496-503.

L. Kang, J.., Kim, Y.., Stulz, R.., 1995. An Analysis of The Wealth Effects of Japanese Offshore Dollar-Denominated Convertible and Warrant Bond Issues. J. Financ. Quant. Anal. 257-270.

M. Kim, C.., Abdullah, N.A.., 2012. The Effect Corporate Bond Issuance to The Equity Market and Its Determinants. Malays. Finance Assoc. Conf.

N. Kim, H.J., Han, S.H., 2019. Convertible bond announcement returns, capital expenditures, and investment opportunities: Evidence from Korea. 
Pac.-Basin Finance J. 53, 331-348.

O. Klein, P.-O., Weill, L., 2016. Why do companies issue sukuk? Rev. Financ. Econ. 31, 26-33.

P. Mujahid, 2010. Pengaruh Penerbitan Obligasi Syariah (Sukuk) Perusahaan terhadap Reaksi Pasar. Pertem. Simp. Nas. Akunt. XIII.

Q. Muklis, F., 2016. Perkembangan dan Tantangan Pasar Modal Indonesia. Al Masraf J. Keuang. Dan Perbank. 1.

R. Nagano, M., 2017. Sukuk issuance and information asymmetry: Why do firms issue sukuk? Pac.-Basin Finance J. 42, 142-157.

S. Ng, A., Ariff, M., 2019. Does credit rating revision affect the price of a special class of common stock? Borsa Istanb. Rev. 19, S44-S55.

T. Pratama, R., 2013. Pengaruh Penerbitan Obligasi Syariah (Sukuk) terhadap Reaksi Pasar Modal Indonesia (Survey terhadap Perusahaan-Perusahaan yang Menerbitkan Obligasi Syariah dan Terdaftar di Bursa Efek Indonesia Selama Tahun 2011). Skripsi.

U. Qizam, I., Fong, M., 2019. Developing financial disclosure quality in sukuk and bond market: Evidence from Indonesia, Malaysia, and Australia. Borsa Istanb. Rev. 19, 228-248.

V. Rachman, R.A., Ervina, D., 2017. Dampak Pengumuman Penerbitan Obligasi Perusahaan Terhadap Abnormal Return Saham Di Indonesia Tahun 2014- 2015. MIX J. Ilm. Manaj. VII(2), 300-315.

W. Razak, S.S., Saiti, B., Dinç, Y., 2019. The contracts, structures and pricing mechanisms of sukuk: A critical assessment. Borsa Istanb. Rev. 19, S21-S33

X. Sari, A.K., 2014. Perbedaan Return Saham Sebelum dan Sesudah Penerbitan Obligasi Syariah (Sukuk) Ijarah pada Perusahaan yang Tergabung dalam Daftar Efek Syariah (DES). EKBISI J. Ekon. Dan Bisnis Islam IX(1), 35-42.

Y. Sartono, A., 2008. Manajemen Keuangan Teori dan Aplikasi. BPFE Yogyakarta, Yogyakarta.

Z. Savitri, E., 2015. Pengaruh Penerbitan Obligasi Syariah (Sukuk) terhadap Reaksi Pasar Modal Indonesia Tahun 2009-2013. J. Apl. Manaj. JAM
13(4).

AA. Shanmugam, B., Zaha Rina Zahari, 2009. A primer on Islamic finance. Research Foundation of CFA Institute, Charlottesville, Va.

BB. Shi, J., Yu, C., Guo, S., Li, Y., 2020. Market effects of private equity placement: Evidence from Chinese equity and bond markets. North Am. J. Econ. Finance 53, 101214.

CC. Spence, A.., 1974. Competitive and Optimal Responses to Signals: Analysis of Efficiency and Distribution. J. Econ. Theory 296-332.

DD. Syarifudin, A., Afiffudin, Mawardi, M.., 2019. Pengaruh Penerbitan Sukuk terhadap Reaksi Pasar Modal Syariah (Studi Empiris di BEI Tahun 2018). E-JRA Fak. Ekon. Dan Bisnis Univ. Islam Malang 8(10). 